\title{
Prospek Pengembangan Usaha Ternak Kambing dalam Usaha Tani Kakao di Desa Banjarharjo dan Banjaroya, Kalibawang, Kulon Progo
}

\author{
(Prospect of Development of Goat Breeding in the Cocoa Farming in Banjarharjo \\ and Banjaroya Villages, Kalibawang Subregency, Kulon Progo Regency)
}

\author{
Werdhany WI, Gunawan \\ Balai Pengkajian Teknologi Pertanian Yogyakarta \\ Jl. Maguwoharjo No. 22, Karangsari, Wedomartani, Ngemplak, Sleman, Yogyakarta 55584 \\ windiedhany@yahoo.com
}

\begin{abstract}
Cocoa waste has potential as goat feed but it is not widely used. The study purposes are to evaluate the cocoa waste prospect as feed and to analyze goat farming in the cocoa plantation. The study was conducted in the villages of Banjarharjo and Banjaroya in two groups of farmers in Gerpule and Padaan Ngasem and two groups of farmers in Plantok Wetan and Slanden, respectively. The respondents of each group was 15 people, thus the total was 60 people. The assessment was conducted from January to December 2015 by utilizing farm record keeping and surveys. The Survey was conducted with interview method using questionnaire, the data collected included data on livestock ownership, the potency of cocoa leaves and cocoa peels, the business income, and availability of labor. Data were tabulated and analyzed descriptively. The potential feed of cocoa leaves and peels for two farmer groups in Banjarharjo and Banjaroya villages was 113.5 and 86.8 tons or 63 and $72 \%$ of goat feed requirement, respectively. Goat business income in Banjarharjo and Banjaroya villages are Rp. 3.300 .750 and Rp. 5.144.180 per year, respectively, regardless the labor cost. The goat business has not been profitable if it takes into the labor cost. The income can be increased by means on increasing the number of livestock marketed and the decrease of number of death lambs.
\end{abstract}

Key Words: Business Analysis, Goat, Waste Cocoa, Feed

\begin{abstract}
ABSTRAK
Limbah kakao potensial sebagai pakan kambing, namun belum banyak digunakan oleh peternak. Penelitian ini bertujuan mengevaluasi prospek pemanfaatan limbah kakao sebagai pakan kambing dan menganalisis usaha ternak kambing dalam usaha tani kakao. Pengkajian dilakukan di Desa Banjarharjo pada dua kelompok tani di Dusun Gerpule dan Padaan Ngasem serta di Desa Banjaroya pada dua kelompok tani di Dusun Plantok Wetan dan Slanden. Responden masingmasing kelompok tani adalah 15 orang sehingga total 60 orang. Pengkajian dilaksanakan bulan Januari-Desember 2015 menggunakan farm record keeping dan survei. Survei dengan metode wawancara menggunakan kuesioner, data yang dikumpulkan meliputi data kepemilikan ternak kambing. potensi daun kakao, potensi kulit buah kakao, pendapatan usaha ternak kambing dan curahan tenaga kerja. Data ditabulasi dan dianalisis secara deskriptif. Potensi pakan dari daun kakao dan kulit buah kakao untuk dua kelompok tani di Desa Banjarharjo dan Banjaroya adalah 113,5 dan 86,8 ton atau memenuhi 63 dan 72\% dari kebutuhan pakan kambing. Pendapatan usaha ternak kambing di Desa Banjarharjo sebesar Rp. 3.300.750 dan di Desa Banjaroya sebesar Rp. 5.144.180 per tahun bila tanpa memperhitungkan biaya tenaga kerja. Usaha ternak kambing belum memberi keuntungan, jika memperhitungkan biaya tenaga kerja. Peningkatan pendapatan dapat melalui peningkatan jumlah ternak yang dipasarkan dan menurunkan jumlah kematian anak kambing.
\end{abstract}

Kata Kunci: Analisis Usaha, Kambing, Limbah Kakao, Pakan 


\section{PENDAHULUAN}

Peternakan kambing merupakan salah satu usaha yang menjanjikan keuntungan bagi petani di pedesaan. Tingginya permintaan daging kambing tidak serta merta membuat usaha peternakan kambing mengalami peningkatan yang signifikan. Usaha ini hanya dijadikan sebagai usaha sampingan oleh para petani di pedesaan dengan jumlah kepemilikan pada kisaran 2-6 ekor per keluarga tani. Populasi ternak kambing di Kabupaten Kulon Progo tahun 2014 sebanyak 90.110 ekor (BPS DIY 2015). Ternak kambing sangat potensial dikembangkan di lahan perkebunan kakao, karena sekitar 6075\% hasil samping kakao dapat dimanfaatkan sebagai bahan pakan ternak kambing. Kulit buah kakao merupakan sumber pakan yang baik untuk ternak kambing (Munier et al. 2009; Puastuti et al. 2015; Werdhany et al. 2012; Wulandari et al. 2014), bahkan sudah ada upaya perbaikan kualitas pakan dari kulit buah kakao (Laconi et al. 2015; Saili et al. 2010; Zakariah et al. 2016). Kulit buah kakao sebanyak 1,25-1,5 kg/hari yang diberikan pada kambing umur 8-12 bulan memberikan pertambahan bobot badan harian (PBBH) 52-70 g/ekor/hari lebih tinggi dibandingkan dengan yang mendapatkan pakan rumput yaitu PBBH sekitar 10 g/ekor/hari (Munier 2009). Hasil pengkajian Gunawan et al. (2013) menunjukkan penggunaan daun kakao sebanyak $2 \mathrm{~kg} / \mathrm{ekor} / \mathrm{hari}$ dapat meningkatkan PBBH ternak kambing sekitar 20\% lebih tinggi dibandingkan dengan menggunakan rumput.

Desa Banjarharjo merupakan lokasi kegiatan model pengembangan bioindustri berbasis tanaman kakao-ternak kambing, sedangkan Desa Banjaroya merupakan pengembangan wilayah pendampingan. Kedua desa memiliki agoekosistem yang sama yakni agroekosistem lahan kering dataran tinggi. Berdasarkan hasil identifikasi penggunaan lahan, luas lahan kakao rata-rata yang dimiliki petani relatif sempit yaitu $1.200 \mathrm{~m}^{2}$ dan kakao ditanam di dalam kebun secara tumpangsari dengan tanaman keras seperti kelapa, durian atau nangka (Gunawan et al. 2015). Selama tiga tahun dalam pendampingan pengkajian integrasi tanaman kakao-ternak kambing, selanjutnya dikembangkan menjadi model bioindustri berbasis integrasi tanaman kakao-ternak kambing. Telah dilakukan implementasi teknologi inovasi baik di bidang peternakan dan perkebunan untuk meningkatkan nilai tambah baik pada produk kakao maupun produk dari ternak kambing untuk medukung petani kakao dalam meningkatkan pendapatannya.

Pengkajian ini bertujuan untuk mengevaluasi prospek pemanfaatan limbah kakao sebagai pakan kambing dan analisis usaha ternak kambing dalam usaha tani kakao di Desa Banjarharjo dan Banjaroya, Kecamatan Kalibawang, Kabupaten Kulon Progo.

\section{MATERI DAN METODE}

Pengkajian ini dilaksanakan dalam kawasan model pengembangan bioindustri berbasis integrasi kambing-kakao yaitu di Desa Banjarharjo pada dua kelompok tani yaitu di Dusun Gerpule dan Padaan Ngasem serta Desa Banjaroya sebagai lokasi pengembangan model yaitu pada dua kelompok tani di Dusun Plantok Wetan dan Slanden. Kedua desa tersebut terdapat di Kecamatan Kalibawang, Kabupaten Kulon Progo.

Pengkajian dilaksanakan pada bulan November-Desember 2015. Responden masingmasing kelompok tani sebanyak 15 orang sehingga total responden berjumlah 60 orang. Pengkajian dilakukan dengan metode survei dan pengamatan/observasi. Survei dilakukan dengan wawancara menggunakan kuesioner.

Jenis data yang dikumpulkan meliputi data kepemilikan ternak kambing. potensi pakan dari limbah kakao (daun kakao dan kulit buah kakao), pendapatan petani dari usaha ternak kambing dan curahan tenaga kerja. Data yang terkumpul selanjutnya ditabulasi dan dianalisis secara deskriptif. Analisis dilakukan terhadap pendapatan usaha ternak kambing 
dan biaya tenaga kerja. Pendapatan usaha ternak kambing diperhitungkan berdasarkan selisih antara penerimaan (tunai dan non-tunai) yang berdasarkan dari perhitungan (cost and return analysis) menurut Amir \& Knipscheer (1989). Besaran biaya tenaga kerja dihitung berdasarkan rumus Priyanto et al. (2005).

$$
\mathrm{BTK}=\mathrm{HOK} \times \mathrm{PBR}
$$

$$
\begin{aligned}
& \mathrm{BTK}=\text { Biaya tenaga kerja/tahun } \\
& \mathrm{HOK}=\text { Curahan tenaga kerja/tahun } \\
& \mathrm{PBR}=\text { Penerimaan bersih rata-rata }
\end{aligned}
$$

$$
\mathrm{HOK}=\frac{\sum \mathrm{jam} \times 360 / \text { tahun }}{5}
$$

$\sum$ jam $=$ Jumlah jam kerja yang dibutuhkan/hari $=5$ jam kerja/hari

$360=$ konversi ke- tahun (360 hari)

\section{HASIL DAN PEMBAHASAN}

\section{Produktivitas kambing}

Jumlah kambing yang dimiliki oleh peternak di Kelompok Tani Desa Banjarharjo dan Banjaroya rata-rata masing-masing adalah 7,7 dan 5,9 ekor dengan jumlah kambing induk sebanyak 3,4 dan 2,5 ekor (Tabel 1).

Tabel 1. Jumlah kambing yang dimiliki oleh peternak di Kelompok Tani Desa Banjarharjo dan Banjaroya, Kalibawang, Kulon Progo

\begin{tabular}{lccccccc}
\hline \hline \multirow{2}{*}{ Jenis } & \multicolumn{3}{c}{ Desa Banjarharjo } & & \multicolumn{3}{c}{ Desa Banjaroya } \\
\cline { 2 - 3 } & $\begin{array}{c}\text { Kambing } \\
\text { (ekor) }\end{array}$ & $\begin{array}{c}\text { Kepemilikan } \\
\text { (ekor/orang) }\end{array}$ & $\%$ & & $\begin{array}{c}\text { Kambing } \\
\text { (ekor) }\end{array}$ & $\begin{array}{c}\text { Kepemilikan } \\
\text { (ekor/orang) }\end{array}$ & $\%$ \\
\hline Kambing induk & 101 & 3,4 & 43,53 & & 74 & 2,5 & 42,05 \\
Kambing muda & 72 & 2,4 & 31,03 & 9 & 0,3 & 5,11 \\
Anak kambing & 59 & 1,9 & 25,44 & 93 & 3,1 & 52,84 \\
\hline Jumlah & 232 & 7,7 & 100,00 & & 176 & 5,9 & 100,00 \\
\hline
\end{tabular}

Jumlah per desa adalah 30 responden dari dua kelompok tani; Setiap kelompok tani tersedia empat ekor pejantan

Jumlah kambing induk pada peternak di Desa Banjarharjo (3,4 ekor/orang) lebih banyak daripada peternak di Banjaroya (2,5 ekor/peternak) sehingga kemungkinan perkembangan kambing yang diperoleh peternak di Banjarharjo juga lebih banyak dibandingkan dengan peternak di Banjaroya. Hal ini sesuai dengan pendapat Budisatria et al. (2010) yang menyatakan bahwa peluang untuk memperbesar usaha ternak kambing antara lain dengan memperbanyak jumlah induk. Perkembangan ternak kambing selama setahun pada dua kelompok tani di Desa Banjarharjo dan Banjaroya ditunjukkan pada Tabel 2.

Perkembangan ternak kambing di kelompok tani di Desa Banjarharjo adalah 11 ekor lebih banyak dibandingkan dengan di Desa Banjaroya yaitu 21 ekor. Anak kambing yang dihasilkan sebanyak 59 ekor (Banjarharjo) dan 93 ekor (Banjaroya). Terdapat peningkatan 
pada jumlah induk kambing sebanyak 29 ekor untuk Desa Banjarharjo dan 11 ekor untuk Desa Banjaraoya. Hasil wawancara dalam survei, menjelaskan bahwa peningkatan jumlah induk kambing berasal dari pembelian dan ternak muda yang telah menjadi induk. Hal ini menunjukkan bahwa pola usaha yang dilakukan oleh peternak pada kedua desa tersebut yaitu untuk usaha pembibitan dengan mengutamakan hasil penjualan anak kambing sebagai sumber pendapatan utama.

Tabel 2. Perkembangan ternak kambing pada dua kelompok tani di Desa Banjarharjo dan Banjaroya selama tahun 2015

\begin{tabular}{lccccc}
\hline \hline \multirow{2}{*}{ Jenis } & \multicolumn{2}{c}{ Desa Banjarharjo } & & \multicolumn{2}{c}{ Desa Banjaroya } \\
\cline { 2 - 3 } \cline { 5 - 6 } & Januari 2015 & Desember 2015 & & Januari 2015 & Desember 2015 \\
\hline Kambing induk (ekor) & 72 & 101 & & 63 & 74 \\
Kambing muda (ekor) & 133 & 72 & & 95 & 9 \\
Anak kambing (ekor) & 0 & 59 & & 0 & 93 \\
\hline Jumlah (ekor) & 205 & 232 & & 158 & 176 \\
\hline
\end{tabular}

Jumlah per desa adalah 30 responden dari dua kelompok tani

Perkembangan ternak kambing di Desa Banjarharjo sebanyak 11 ekor diperoleh dari jumlah kelahiran 59 ekor dikurangi kematian anak 16 ekor, dikurangi penjualan 36 ekor dan ditambah pembelian sebanyak empat ekor. Perkembangan ternak kambing di Banjaroya lebih banyak yaitu 21 ekor diperoleh dari jumlah kelahiran 93 ekor dikurangi kematian 23 ekor, dikurangi penjualan 57 ekor dan ditambah pembelian sebanyak 8 ekor.

\section{Potensi pakan}

Di Desa Banjarharjo dan Banjaroya, pakan hijaun untuk kambing berasal dari pemanfaatan hasil pemangkasan daun kakao yang melimpah pada saat melakukan perawatan tanaman kakao (pangkas daun) dan kulit buah kakao yang diperoleh setelah diambil buahnya. Ternak kambing pada wilayah desa tersebut telah terbiasa mengonsumsi daun kakao baik dalam bentuk segar maupun diawetkan dalam bentuk silase. Sebagai sumber pakan hijauan, di kedua desa tersebut sangat melimpah dan sangat mendukung perkembangan usaha ternak kambing. Hasil pemangkasan daun yang melimpah disimpan dalam bentuk silase yang setiap saat dapat dimanfaatkan sebagai pakan kambing demikian pula kulit buah kakao yang umumnya masih menjadi limbah dan dibuang.

Luas lahan kakao milik petani pada dua kelompok tani di Desa Banjarharjo sekitar 8,5 ha sedangkan di Banjaroya sekitar 6,5 ha. Berdasar luas lahan tersebut, maka terdapat potensi pakan hijauan daun kakao dari hasil pemangkasan daun dan ranting untuk membuat bentuk tanaman muda dan meningkatkan produksi pada tanaman dewasa yang dilakukan secara bergotong royong pada kebun milik anggota. Pemangkasan daun kakao dilakukan setiap dua minggu sekali dengan hasil daun kakao sebanyak rata-rata $100 \mathrm{~kg} / 0,2$ ha kebun kakao. Dengan demikian untuk dua kelompok di Desa Banjarharjo dapat menghasilkan daun kakao sebanyak 8,5 ton/bulan atau 102 ton/tahun dan 6,5 ton/bulan atau 78 ton per tahun untuk di Desa Banjaroya. Jika diolah dalam bentuk silase daun kakao akan menghasilkan sebanyak 6,4 ton/bulan untuk Desa Banjarharjo dan 4,8 ton/bulan pada Desa Banjaroya, karena diasumsikan dalam setiap kilogram daun kakao segar dapat dihasilkan $0,75 \mathrm{~kg}$ silase daun kakao (75\%). Dari setiap kebun kakao di Kalibawang umumnya dihasilkan kulit buah kakao sekitar 1,36 ton/tahun sehingga dari luas kebun 
kakao 8,5 ha di Banjarharjo dan 6,5 ha di Banjaroya juga dihasilkan kulit buah kakao sekitar 11,5 dan 8,8 ton/tahun.

Berdasarkan asumsi pemberian pakan sebanyak $10 \%$ berat badan dari bobot kambing induk $30 \mathrm{~kg}$, bobot kambing muda $20 \mathrm{~kg}$ dan bobot anak kambing $10 \mathrm{~kg}$, maka jumlah pakan hijauan yang diperlukan untuk ternak kambing pada dua kelompok tani di Banjarharjo dan Banjaroya dapat diketahui yaitu masing-masing sekitar 0,5 ton/hari atau 180 ton/tahun dan 0,33 ton/hari atau 120 ton/tahun. Dengan demikian, maka potensi pakan yang tersedia dari daun kakao dan kulit buah kakao untuk dua kelompok tani di Desa Banjarharjo dan Banjaroya adalah 113,5 dan 86,8 ton atau dapat memenuhi 63 dan 72\% dari kebutuhan. Kekurangan pakan itu dapat dipenuhi oleh petani dari rumput dan daundaunan yang diperoleh petani dengan mengarit. Dengan demikian, penggunaan daun kakao dan kulit buah kakao sebagai pakan kambing dapat mengurangi penggunaan rumput, sesuai pendapat Puastuti (2009) yang menyatakan bahwa penggunaan limbah kakao dapat mengurangi waktu petani dalam merumput.

\section{Pendapatan usaha ternak kambing}

Pendapatan petani dari usaha kambing di Desa Banjarharjo rata-rata adalah Rp. 3.300.750 lebih rendah dari petani di Banjaroya yaitu Rp. 5.144.180/tahun (Tabel 3). Hal ini terutama karena rendahnya jumlah penjualan ternak kambing di Desa Banjarharjo dibandingkan dengan di Desa Banjaroya. Jumlah penjualan ternak kambing pada dua kelompok tani di Desa Banjarharjo yaitu sebanyak 36 ekor/tahun sedangkan di Desa Banjaroya adalah 57 ekor/tahun, sedangkan jumlah pembelian ternak kambing masingmasing adalah 4 dan 8 ekor/tahun dan kematian kambing masing-masing adalah 16 dan 23 ekor/tahun.

Tabel 3. Pendapatan rata-rata petani di Desa Banjarharjo dan Banjaroya dari usaha ternak kambing tahun 2015

\begin{tabular}{|c|c|c|c|c|}
\hline \multirow{2}{*}{ Uraian } & \multicolumn{2}{|c|}{ Banjarharjo } & \multicolumn{2}{|c|}{ Banjaroya } \\
\hline & Volume & Nilai (Rp) & Volume & Nilai (Rp) \\
\hline \multicolumn{5}{|l|}{ Penerimaan } \\
\hline Penjualan kambing & 1,2 ekor & 3.180 .000 & 1,9 ekor & 5.035 .000 \\
\hline Perkembangan ternak kambing & 0,8 ekor & 1.060 .000 & 0,8 ekor & 1.060 .000 \\
\hline Penjualan pupuk organik & $232,5 \mathrm{~kg}$ & 232.500 & $0 \mathrm{~kg}$ & 0 \\
\hline Jumlah (Rp/tahun) & & 4.472 .500 & & 6.095 .000 \\
\hline \multicolumn{5}{|l|}{ Biaya } \\
\hline Pembelian kambing & 0,65 ekor & 861.250 & 0,4 ekor & 530.000 \\
\hline Pembelian dedak untuk silase & $1,7 \mathrm{~kg}$ & 4.250 & $4,2 \mathrm{~kg}$ & 10.500 \\
\hline Pembelian bahan mineral blok & 3,25 cup & 16.250 & 2,7 cup & 13.500 \\
\hline Obat-obatan & 1 paket & 40.000 & 1 paket & 40.000 \\
\hline Kandang & 1 kali & 250.000 & 1 kali & 250.000 \\
\hline Jumlah (Rp/tahun) & & 1.171 .750 & & 844.000 \\
\hline Pendapatan dari usaha kambing ( & un) & 3.300 .750 & & 5.144 .180 \\
\hline
\end{tabular}

Harga penjualan kambing Rp. 2.650.000/ekor, harga perkembangan/pembelian kambing Rp. 1.325.000/ekor, harga pupuk organik Rp. $1.000 / \mathrm{kg}$, harga dedak padi Rp. $2500 / \mathrm{kg}$, harga bahan mineral blok Rp. 5.000/cup, biaya obat-obatan Rp. 40.000/paket, biaya pemeliharaan kandang Rp. 250.000/tahun 
Faktor yang berpengaruh pada pendapatan petani dari usaha kambing ini adalah hasil penjualan terutama pada saat menjelang hari raya Idul Adha, karena pada saat hari raya Idul Adha harga jual kambing meningkat hingga 1,6 kali dibandingkan pada saat hari biasa, sesuai dengan pendapat Budisatria et al. (2008). Untuk itu, maka strategi pemasaran perlu diperhatikan dalam upaya meningkatkan pendapatan petani.

\section{Penggunaan tenaga kerja}

Umumnya tenaga kerja petani dalam merawat kambing tidak diperhitungkan, namun bila diperhitungkan maka biaya penggunaan tenaga kerja dalam usaha ternak kambing dapat dilihat pada Tabel 4.

Tabel 4. Rata-rata tenaga kerja yang digunakan dalam memelihara ternak kambing/petani

\begin{tabular}{|c|c|c|c|c|c|c|}
\hline Jenis pekerjaan & $\begin{array}{l}\text { Jam/hari/ } \\
30 \text { petani }\end{array}$ & $\%$ & $\begin{array}{l}\text { Jam/hari/ } \\
\text { petani }\end{array}$ & $\begin{array}{l}\text { Jam/tahun/ } \\
\text { petani }\end{array}$ & $\begin{array}{l}\text { HOK/tahun/ } \\
\text { petani }\end{array}$ & Rp/tahun \\
\hline \multicolumn{7}{|l|}{ Banjarharjo (n: 30) } \\
\hline $\begin{array}{l}\text { Mempersiapkan dan } \\
\text { memberi pakan }\end{array}$ & 45,71 & 64,00 & 1,52 & 547 & 110 & 2.750 .000 \\
\hline Melepas ternak di kebun & 8,57 & 12,00 & 0,29 & 104 & 21 & 525.000 \\
\hline $\begin{array}{l}\text { Perawatan dan } \\
\text { membersihkan kandang }\end{array}$ & 17,14 & 24,00 & 0,57 & 205 & 41 & 1.025 .000 \\
\hline Jumlah & 71,42 & 100,00 & 2,38 & 856 & 171 & 4.300 .000 \\
\hline \multicolumn{7}{|l|}{ Banjaroya (n: 30) } \\
\hline $\begin{array}{l}\text { Mempersiapkan dan } \\
\text { memberi pakan }\end{array}$ & 36,00 & 45,65 & 1,20 & 432 & 86 & 2.160 .000 \\
\hline Melepas ternak di kebun & 30,00 & 38,04 & 1,00 & 360 & 72 & 1.800 .000 \\
\hline $\begin{array}{l}\text { Perawatan dan } \\
\text { membersihkan kandang }\end{array}$ & 12,86 & 16,30 & 0,43 & 155 & 31 & 775.000 \\
\hline Jumlah & 78,86 & 100,00 & 2,63 & 947 & 189 & 4.735 .000 \\
\hline
\end{tabular}

$1 \mathrm{HOK}=5$ jam kerja; $1 \mathrm{HOK}=$ Rp. 25.000; 1 tahun dihitung 360 hari

Berdasar Tabel 4 rata-rata tenaga kerja yang dibutuhkan setiap keluarga petani untuk memelihara ternak kambing dengan jumlah ternak yang dipelihara rata-rata 7,7 ekor untuk Desa Banjarharjo sebesar 856 jam/tahun atau $171 \mathrm{HOK}$ dan jika diperhitungkan $1 \mathrm{HOK}=$ Rp. 25.000 maka untuk memelihara ternak kambing membutuhkan biaya sebesar Rp. 4.275.000/tahun. Dengan demikian, jika kita perhitungkan tenaga kerja keluarga maka petani Banjarharjo belum merasakan keuntungan karena pendapatannya Rp. 3.300.750 dikurangi biaya tenaga kerja sebesar Rp. 4.300.000 maka akan minus Rp. 999.250.

Demikian juga petani Desa Banjaroya, dengan rata-rata kepemilikan ternak 5,9 ekor rata-rata petani membutuhkan tenaga kerja untuk merawat ternak sebesar 947 jam/tahun atau 189 HOK dan setiap petani membutuhkan biaya tenaga kerja sebesar Rp. 4.735.000 setahun sehingga jika diperhitungkan tenaga kerja keluarga, maka pendapatan petani Banjaroya dari pemeliharaan ternak hanya surplus Rp. 409.180 (Rp. 5.144.180-4.735.000).

Memperhatikan potensi hijauan dan pakan yang banyak tersedia pada ke dua desa lokasi kelompok peternak, serta pemanfaatan waktu per hari per petani rata-rata hanya 2,3 dan 2,6 jam, maka masih perlu meningkatkan jumlah ternak yang dipelihara serta strategi pemasaran ternak hingga peternak dapat merasakan keuntungan dengan memperhitungkan tenaga kerja pemeliharaan. 
Meskipun dari segi kebutuhan tenaga pemeliharaan petani desa Banjarharjo lebih efisien dibandingkan denagn petani Desa Banjaroya, namun pola yang diterapkan petani Desa Banjaroya dengan memperhitungkan keuntungan dalam sistem perdagangan ternak melalui pembelian dan penjualan ternaknya, dapat menekan kerugian tenaga kerja dan memberi keuntungan lebih banyak dibandingkan dengan peternak Desa Banjarharjo. Dengan demikian, bagi peternak Desa Banjarharjo, perlu merubah strategi pemasaran ternak dengan meningkatkan jumlah ternak yang dijual sehingga jika tenaga kerja diperhitungkan, peternak dapat merasakan keuntungan dalam memelihara ternak kambing. Disamping itu, kematian anak kambing/kambing muda kelompok peternak di kedua desa masih terlalu tinggi, yaitu 16 ekor (Banjarharjo) dan 23 ekor (Banjaroya) harus ditekan sehingga dapat menambah jumlah ternak yang dipelihara.

\section{KESIMPULAN}

Pengembangan usaha ternak kambing di Desa Banjarharjo dan Banjaroya dapat dilakukan dengan lebih mengoptimalkan pemanfaatan limbah kakao sebagai pakan kambing. Pemeliharaan kambing dapat memberikan sumbangan pendapatan bagi petani di Desa Banjarharjo dan Banjaroya sebesar Rp. 3.300.750-5.144.180 per tahun bila tanpa memperhitungkan biaya tenaga kerja. Jika memperhatikan tenaga kerja, maka usaha ternak kambing belum banyak memberi keuntungan bagi petani. Strategi yang perlu dilakukan untuk meningkatkan pendapatan petani dari usaha ternak kambing adalah meningkatkan jumlah ternak yang dipasarkan dan menurunkan jumlah kematian anak kambing.

\section{DAFTAR PUSTAKA}

Amir P, Knipscheer H, 1988. Conducting on farm research procedures and economic analysis. Singapore (Singapore): Winrock International Institute for Agricultural Development and International Research Center. Singapore National Printers Ltd.

Ardjanhar A, Langsa Y, Femmi NF. 2009. Optimalisasi produktivitas tanaman kakao dan kambing melalui perbaikan budidaya secara terintegrasi. Dalam: Haryanto B, et al., editors. Prosiding Lokakarya Nasional. Sistem Integrasi Tanaman-Ternak. Bogor (Indonesia): Puslitbangnak.

BPS DIY. 2015. Daerah Istimewa Yogyakarta dalam Angka. Yogyakarta (Indonesia): Badan Pusat Statistik Daerah Istimewa Yogyakarta.

Budisatria IGS, Eilers CHAM, Udo HMJ, Baliarti E, van der Zijpp AJ. 2010. Preferences for sheep or goats in Indonesia. Small Rum Res. 88:16-22.

Budisatria IGS, Udo HMJ, van der Zijpp AJ, Baliarti E, Murti TW. 2008. Religious festivities and marketing of small ruminants in Central Java. Asian J Agric Dev. 5:57-74.

Gunawan, Werdhany WI, Sukar, Budiarti SW, Siswanto TJ, Widyayanti S, Sutarno, Astuti EP. 2013. Model pengembangan tanaman kakao integrasi dengan ternak kambing di Kabupaten Kulon Progo. Laporan Akhir Tahun 2013. Yogyakarta (Indonesia): Balai Pengkajian Teknologi Pertanian Yogyakarta.

Gunawan, Werdhany WI, Sukar, Hatmi U, Titiek F, Djaafar, Winarti E, Astuti EP, Astri C, Wirasti, Suparjana, Marthon A, Suparta G, Sutarno, Nilawati M, Jumanto. 2015. Model pengembangan pertanian bioindustri berbasis integrasi tanaman ternak di DI Yogyakarta. Laporan Akhir Tahun 2015. Yogyakarta (Indonesia): Balai Pengkajian Teknologi Pertanian Yogyakarta.

Laconi EB, Jayanegara A. 2015. Improving nutritional quality of cocoa pod (Theobroma cacao) through chemical and biological treatments for ruminant feeding: in vitro and in vivo evaluation. Asian-Australian J Anim Sci. 28:343-350. 
Munier FF. 2009. Bobot hidup kambing betina Peranakan Ettawah (PE) yang diberikan pakan tambahan daun gamal (Gliricidia sepium) dan kulit buah kakao (Theobroma cocoa L). Dalam: Haryanto B, et al., editors. Prosiding Lokakarya Nasional. Sistem Integrasi Tanaman-Ternak. Bogor (Indonesia): Puslitbangnak.

Priyanto D, Setiadi B, Yulistiani D. 2000. Potensi kambing Peranakan Ettawa (PE) dan upaya pola konservasi di daerah sumber bibit. Dalam: Haryanto B, Darminto, Hastiono S, Sutama IK, Partoutomo S, Subandriyo, Sinurat AP, Darmono, Supar, Butar-Butar SO, penyunting. Prosiding Seminar Nasional Peternakan dan Veteriner. Bogor, 18-19 September 2000. Bogor (Indonesia): Puslitbangnak.

Puastuti W, Widiawati Y, Wina E. 2015. Digestion and ruminant fermentation of cocoa pod silage based ration enriched by gliricidia and calliandra leaves on goats. Indonesian J Anim Vet Sci. 20:31-40.

Puastuti W. 2009. Pengolahan kotoran ternak dan kulit buah kakao untuk mendukung integrasi kakao- ternak. Dalam: Haryanto B, et al., editors. Prosiding Lokakarya Nasional. Sistem Integrasi Tanaman-Ternak. Bogor (Indonesia): Puslitbangnak.

Saili T, Marsetyo, Poppi DP, Isherwood P, Nafiu I, Quigley SP. 2010. Effect of treatment of cocoapods with Aspergillus niger on liveweight gain and cocoa pod intake of Bali (Bos sondaicus) cattle in South-East Sulawesi. Anim Prod Sci. 50:693-698.

Werdhany WI, Utami R, Gunawan. 2012. Teknologi pengolahan kulit buah kakao untuk penyediaan pakan ternak kambing. Dalam: Integrasi kambing kakao. Yogyakarta (Indonesia): Balai Pengkajian Teknologi Pertanian Yogyakarta.

Wulandari S, Agus A, Cahyanto MN, Utomo R. 2014. Effect of fermented cacao pod supplementation on sheep rumen microbial fermentation. J Indonesian Trop Anim Agric. 39:167-174.

Zakariah MA, Utomo R, Bachruddin Z. 2016. Pengaruh inokulasi Lactobacillas plantarium dan Saccharomyces cerevisiae terhadap fermentasi dan kecernaan in vitro silase kuli buah kakao. Buletin Peternakan. 40:124-132.

\section{DISKUSI}

\section{Pertanyaan}

Berapa produksi daun kakao hasil pangkasan/ha?

\section{Jawaban}

Produksi daun $100 \mathrm{~kg} / 0,2 \mathrm{ha}$. 